VII-1 | 2015

The Pragmatist Method

\title{
Civility and Democracy
}

\section{Carole Gayet-Viaud}

\section{OpenEdition}

\section{Journals}

Electronic version

URL: http://journals.openedition.org/ejpap/372

DOl: 10.4000/ejpap.372

ISSN: 2036-4091

\section{Publisher}

Associazione Pragma

\section{Electronic reference}

Carole Gayet-Viaud, « Civility and Democracy », European Journal of Pragmatism and American Philosophy [Online], VII-1 | 2015, Online since 07 July 2015, connection on 20 April 2019. URL : http:// journals.openedition.org/ejpap/372 ; DOI : 10.4000/ejpap.372

This text was automatically generated on 20 April 2019.

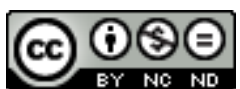

Author retains copyright and grants the European Journal of Pragmatism and American Philosophy right of first publication with the work simultaneously licensed under a Creative Commons AttributionNonCommercial-NoDerivatives 4.0 International License. 


\title{
Civility and Democracy
}

\author{
Carole Gayet-Viaud
}

\section{Introduction}

1 If we take seriously the idea that democracy is not only a political regime but also a way of life, in another sense, if we admit, as Lefort (1986) puts it, quoting Strauss, that politeia means "regime" in the sense of a form of government and more profoundly and widely in the sense of a form of life, as rendered by the expression "Ancien Regime" for prerevolutionary France, then we cannot agree to the usual a priori divide between "the social" and "the political" spheres.

The distinction between morals and manners (and the loss of the unity of the ancient "mores") is a form of this more general dichotomy between the social world of practices, and the political (or moral) world of principles, that a pragmatist approach helps to overcome (Putnam 2004). Following Dewey's important stance according to which ideas and practices are organically related and, whilst they can be analytically distinguished as steps in a process, are never more than aspects or moments in a continuous and dynamic phenomenon (1938, French translation 2006: 598), I shall make the case for a study of political principles as they appear and they are put into play, expressed, fought for, in urban civil interactions.

3 Civility will be considered here as: a part of public life, a part of the everyday experience of citizenship, an on-going activity, as opposed to a set of pre-defined superficial social rules that one should only have to apply, that is, without ever really thinking about their meaning or legitimacy, but rather "blindly" or even without thinking at all. Considering civility as an active part of practicing democracy as a way of living together in a political community will, therefore, require us to admit at least three ideas, which I shall attempt to defend:

1. Civility does not embody 'the social' as opposed to 'the political.' Rather, it navigates between these two polarities of the public, between a notion of the public, that can be considered as representing the potential tyranny of the second person and an opposite 
conception, referring to what is commonly considered to be the mark of the political, that is, action, going along with the emergence of an autonomous first person before others (Arendt 1983) committed to what they care about, and trying to defend what they think is right, true, and worthy. To conceive the connection between these two polarities of the public, one has to acknowledge that what is political cannot be reduced to the model of 'action' or 'militancy.' Rather, politics should be seen as going its own way through culture and experience. Its analysis should therefore focus upon temporality, rather than topography (seeking the places where politics happen). Taking civil interactions as a starting point helps consider it to be utterly processual, rather than only eventful.

2. Civility is never a mere performing of rules and habits. It is also an ongoing work on (and not only within or under) the rules of civility and their legitimacy, that is: how and why they should be understood, applied and hierarchized. Therefore, customs and rules have to pass the test of principles, such as equality, liberty, fraternity, justice. The tensions between them continuously appear in everyday interactions and have to be dealt with as practical issues. Paying attention to what is situationally right, it is misleading to describe civil practices and conduct as being either on the right or on the wrong side of the rule. Such a spatial and binary apprehension of rules and of civility must therefore be criticized and overcome.

3. In civil interactions, ordinary categorization should not be considered merely as a resource, but also as a theme (Zimmerman \& Pollner 1970) for critique and even contention, contributing to forming the citizen's perception and opinion of and about the world they live in. This is one of the ways through which civil activity contributes to democracy: participating in the constitution of the 'Public Opinion,' in the Kantian or Arendtian noble sense of the term. Public debates and the media are often considered to be the two major producers of public opinion (along with "private" sources and families). But they are not the only forces which form and inform opinion. Such agencies of data production, that is, urban interaction experiences, are for sure less easy to compose and study. Yet they are no less real. They are probably one of the major sets of data in which perception of others and of what can be done with and among them is forged and tested.

Each one of these three ideas will be attended to in the following.

\section{Civility and the Two Dimensions of 'the Public.' The Public Dimension in/of Civil Encounters}

5 Civil interactions are encounters in public in which individuals experience others as strangers, are exposed to the gaze of others upon them, and the judgements that go with this experience. This quality of publicity as exposure to anonymous others and to their possible judgement, as well as to the risks that such surveillance encompasses, has often been described as representing a possible obstacle to individual freedom. This social dimension of the 'publicity' of urban life, of the interaction order notably, has been particularly closely analysed by Goffman (1959; 1963; 1971). Quoting Sartre among others, he insists upon the quality of threat that goes along with the public condition of social life, the weight that bears upon one's shoulders as soon as one knows that others are staring. This condition is what makes "impression management" (Goffman 1959: chapter 6) a central part of urban life, and urban dwellers ultimately "performers" (Goffman 1959) in public settings.

6 Such a dimension has even been considered and described as the quintessence of the social condition, and more even of urban life, as an exemplary form of modern social life, 
with its decline of traditional sociability and of solid durable ties. Of course, in contrast, the "strength of weak ties" (Granovetter 1973) has been argued for, from Simmel (1950) to Lofland (1998). Yet the importance and the relevance of such public sociability, as far as the vitality of a political community is concerned, seems to have been far less acknowledged.

Many contemporary theories of civility consider such public sociability as representing a set of rules and constraints that are typical of the social realm. Hence, they are considered superficial, relying upon appearances and conventions, as opposed to what is real and authentic both morally (which is to be found behind appearances, ${ }^{1}$ these latter being on the contrary, caught up in manners and forms) and politically, that is, the realm of freedom, public debate, and action. In this opposition, the constitution of enlightened opinions requires that citizens be detached from their ordinary selfish embodied shortsighted preoccupations - that is, their existence as social beings. The political is then understood as having to be forged apart from, and against the social, as a gesture of irruption, pulling-out/pulling off.

Most contemporary debates concerning civility (Tassin \& Murard 2006; Boltanski \& Esquerré 2014; Habib \& Raynaud 2012) seem to be stuck in a binary opposition that has much to do with this dichotomy between a conventional, artificial, passively inherited 'social' on the one hand, which free political action should escape from, and an irruptive gesture characterizing real action, with its decisive capacity for renewal, on the other. This binary vision opposes two notions of the public. ${ }^{2}$ The first can be called Goffmanian (Goffman 1959; 1963; 1971), and the other Arendtian (Arendt 1983). The first is all about what the others expect from us. It is a theatrical, dramaturgical model of the public, made up of social customs, the culture understood as an inherited tradition stuffed with constraints and more or less ill-founded authority, and reproduced through a mixture of routine and fear of the judgement of others. Success there relies upon "impression management" (Goffman 1959). This social gangue embodies what I call here a "tyranny of the second person,' that is, the anticipation of what you think prevails in (and potentially determines) the way that I behave.

9 As political philosophy understands it, the public domain, the domain of free action, is at the opposite side of this duality: the public then represents the conditions through which emerge the action of an $I$, who appears and exposes herself among others. It is then the reign of 'the first person.' In such a binary opposition, genuine, true political action has nothing to do with customs or habits. It must, on the contrary, tear the veil of the social to appear in its political newness.

In this dual opposition, civility is ordinarily positioned without discussion and even as a textbook case on the side of rituals and formal ceremonies (as opposed to 'substantial' ones: see Goffman 1959). It is said, after all, to represent the paradigmatic example of 'social rules' or 'social conventions.' Indeed, if we make "impression management" the centre of civil exchange, then we cannot disagree that it mainly deals with what is expected from us, not what we think is good, fair, or true, that is, the ways things are, not the way they should be. These latter values are said to be sought for elsewhere, not at the surface of things and conducts. According to this perspective, routines, appearances, social niceties represent the social as a threat to what is really of value.

But it can alternatively be theorized and shown that civil interactions are, in fact, a way through which people deal with those two dimensions of public life and publicity. They do care and work hard for the sake of appearances, and therefore do fall under the control of 
others. But they also, at the same time, show great concern for what is true, fair, what should be promoted or what should be allowed to happen, what should be possible, normal, or unacceptable in the world they live in, and sometimes feel responsible for. In some situations, being a spectator goes along with responsibility. Attending a situation sometimes goes along with a minimal sense of being responsible for what happens before one's eyes. In public settings, definitions of the perimeter of such a responsibility are forged and tested all the time, and they should be considered part of public life in a broad political way. Civil interactions, therefore, will be, in this view, considered as the activity of defining, between strangers in public, what people owe one another, can expect from one another, and can do together. Civility should, therefore, be regarded as a way through which people deal with the essential hybridity, the temporal, processual, and 'impure' quality of their political (and moral) life.

I will discuss civility and its difficulties later, for some of them have much to do with this tension, and apparent dichotomy, between two notions, actually, two dimensions, of the public, that is, the reign of customs, manners, and appearances, on the one hand, and the realm of action, expression, and truth, on the other.

\section{Civility Beyond the Admitted Evidence and Facility of a Rule-Patterned Activity}

13 Civil interactions display a sense of the public that is very profoundly linked to what a democracy is, that is, a way of trying to define, but never from scratch, the best way to live together as a political community. It always happens in a world that is already there, the constraints and demands of which weigh upon us. There are rules and expectations, partly inherited. People try at the same time to prove competent as performers in practicing these rules, and to change how they are understood and performed, how they are hierarchized, and even, of course, their very existence.

The two assertions according to which civility is a part of public life, in the noble sense of the term, and more than a mere list of superficial codes, are deeply intertwined. This is so because performing civility is never just a matter of applying rules, "maintaining normal appearances" (Goffman) or: "doing being ordinary" (Sacks 1985)3. It also, often, deals with trying to promote what is fair. These two aspects may sometimes go accordingly, but they sometimes enter into tension and compete.

The current doxa about civility, derived from Goffman, is that civility works mainly because it is simple, impersonal, costs little, and does not mean much (Goffman 1971). Hence, of course, as far as public encounters are concerned, in cases of disagreement people always prefer to overlook and walk away than to discuss over what is true or fair. What allows and requires us to overcome this reductive functionalist perspective in civil exchange is a discovery from ethnographic fieldwork ${ }^{4}$. People do care enough to quarrel and fight, quite a lot, about civility and its requirements.They take it personally when things don't go well, they insist on making their point, defending their view, not letting some behaviours they fiercely disapprove go without protesting or being one way or another informally sanctioned (Ogien 1990).

The frequency and the intensity of conflicts, whether taking place in public transportation, streets, or queues, shows three things. First, not everyone agrees on what are the rules that matter most, how they should be interpreted (that is understood and 
performed ${ }^{5}$ ), and which shall prevail in such or such a situation. Second, the commonly admitted distinction between civil and uncivil people does not stand. Observations and interviews show that the same people continuously go from respecting to not respecting rules, according to the circumstances. And of course, what is perceived as a sign of disdain when seen in others' behaviours is not when applied to one's own. As Katz showed regarding "pissed off drivers" (Katz 1999), people are prompt to perceive the others' behaviours as symptomatic of a lack of respect or education, but rarely consider their own breach of the rule as representative of a general attitude towards rules or towards the others. Third, the great number of fights proves that maintaining face is not always what people care most about, even in public settings. They sometimes choose to endanger their face and waste time, just to be able to make their point about what they think is right or fair.

The strength of the emotions incurred in civil interactions is quite remarkable in itself. All the more so as people do not seem to make sense of their own emotions. Indeed, within situations or afterwards, they often blame themselves for reacting in disproportionate ways. They cannot seem to understand why they react so intensely, so vividly, to situations or conduct that "should not really matter," since they involve people that "they will never see again." Everything seems to contribute to make civil interactions negligible, insignificant. They are fleeting relationships with unknown people. They are said to produce nothing, and people consider they are not "really themselves anyway," since they are anonymous shadowy presences.

That is why these feelings are sometimes difficult to explain. People describe themselves as "irrational" for caring so much about these situations, but as researchers we have to give this widely observable phenomenon credit for its rationality. The rationality of these emotions relies upon this articulation between facts and ideas, conduct and principles. People care for appearances because they tell them something. Even though this connection can be manipulated, it remains essential to our lives and our perceptions of each other's conduct.

19 Civil rules and codes are often said to be superficial and merely functional, enabling us to pass by, minding one's own business. But people prove to be fiercely attached to what they actually express when things do not go as they think they should. They become angry, even though they sometimes forgo rationality for the sake of these violent emotions. Why do we feel so angry about it since "it does not matter," because, "what does it change, five more minutes of waiting?" It is obvious that what is at stake is $a$ sensible, situated, and embodied definition (perception) of what one's responsibility towards others and the world understood as something people share is. Civil interactions put matters of principle into play. People put trust in conduct to express what they think. Hence the importance of sentences heard during quarrels, such as: "who do you think you are?," "you cannot think you can behave like that and take away with it." What is at stake is what people think they can do in public, with and among others. Conduct is perceived and understood as interpretations and illustrations of how people position themselves towards others. In these situations, the connection between the conduct and what it is supposed to mean in a historically and conventionally established sense is taken very seriously. This very link is the only thing that enables the possibility of a lie, that is, of a secondary disconnection between meaning and signs, an instrumentalization of the signs aimed to express something other than what they usually mean, or are supposed to mean - for example, being nice and helpful in order to steal an elderly lady's handbag. 
Since Goffman, sociologists have habitually recognized and emphasized the efforts made by people in public to behave properly, save face, appear 'normal,' be reliable and predictable, not raise attention, go unnoticed. They have also habitually distinguished between what people show, the tribute they pay to the interaction order and on the other hand, what they really think or feel. Sociologists should, Goffman suggests, consider seriously what is done independently of what is really thought. But in this idea of what people expect us to do we may lose sight of what we want to do.

\section{Civility as an Activity of Defining What We Owe One Another and What We Can Do With and Among Others in Public}

Ethnography shows civility is an activity through which people actually work hard on trying to combine, compose, and make coherent the two dimensions of the public, that is, anticipation of the judgement of others and affirmation of what it is worth from a first person perspective. It is an activity of defining how to behave properly and fairly with and among others. People try to recognize what can be done and what has to be done, that is, customs and sense of justice. They behave according to social conventions but they also try, sometimes with difficulty, to promote what they think is fair and good, and even go against what is said to prevail in the micro-order of public interactions (face). Then people experience trouble, unease, and perplexity. They feel puzzled, they discuss, investigate. They do not always prefer to save face, "remain negligible" (Goffman 1971), save "normal appearances" and let go. When applying so-called 'codes,' people express what they think is fair through them. They select, twist, insist, modulate, in other words, they make efforts to make the codes reflect the actual feelings they have towards a situation and its other participants.

In other words, people rely upon customs and habits and rules and categories of perception that are socially constituted, but this does not mean that these rules or habits or customs are fake, superficial, and untrue. In most cases, people share this mainstream sociological idea that rules of civility are "just codes." Hence they are said not to really express what people actually think, or feel "inside." Yet this opposition becomes much less obvious when one looks closer, taking into consideration the way people react when they are not given the amount of respect they expect and think they deserve. People do perceive that what is expressed through civil conduct actually means something, and they care very much about this 'something.'

When civility is reconsidered, the idea of what is 'civil' or what 'respect' is must be conceived at a distance from Durkheim's models of the sacred (Durkheim 2003), a loaded model that Goffman in turn used extensively. Indeed, the religious model, in all its prestige, confines the relationship with respect within a binary apprehension. Faced with something sacred, defined by the fact of being both separate and forbidden, there are only two possible stances: conformation or transgression (which is profanation). Inaccessibility thus imposes itself as its unavoidable reverse side. The proper, respectful, distance is drawn on the basis of a space, which means absolutely out of reach. Thus spatiality almost entirely represents the type of competency that is expected. To respect is to remain outside, to refrain from touching, to keep back. Obedience to requirements which are made commonplace in this manner, entirely subordinated to a wider use of the 
spatial metaphor, does not take place so much by appropriation or by the accomplishment of a positive performance, as by an uncompromising form of reverent withdrawal. On the contrary, thinking about the acrobatics of consideration is an invitation to conceive the undecided outlines of a third term which goes beyond the choice between a conformism that is bogged down in passivity, and an audacity which continuously threatens to turn into aggressiveness. Here is a requirement for civil exchange which is more ambitious than the mere absence of profanation allows one to envisage.

When facing a beggar asking for help and a coin or two in the métro or in the street, when someone seems to jump a queue, or just stands in the way when everyone hurries, what is at stake is never simply rules. People experience strong emotions (sympathy, shame, trust or suspicion, anger) and are conflicted when trying to define how to behave properly. They talk about it afterwards with friends and relatives. They read avidly about these experiences in the press and in literature. Advertising also constantly refers to these shared experiences of urban public life. But few scholars have acknowledged how important these experiences of coexistence are in people's lives from either a moral or a political perspective. No academic attention has been paid to how people are tormented for some time about some incident that did not go well, and become angry with themselves thinking about what they should have said or done.

Contrary to what the common binary rule-perspective suggests, civility is often caught up in tensions between several rules that have to be hierarchized, and several parallel risks, or potential flaws that have to be taken into consideration and avoided, that is, indifference or intrusion, suspicion or candour and so on. Of course, there are rules defining ways and reasons (resources, small talk) to address one another or not in the streets, but they are themselves judged and criticized, and that is why they change. In the situations outlined above, what has to be defined, for practical purposes, in the situation is what the civil link is and should be, and to what extent it entails solidarity or charity or gallantry or mere indifference or even fear (between whom, on what conditions), and what those actually mean, practically speaking.

When interviewed about how they perceive their interactions with beggars, ${ }^{7}$ people have a whole collection of stories and of all the different attitudes and conduct they tried and tested to face the problem. They have many stories about how they felt when they saw this one -- nice because there was humour and sympathy -- or, on the contrary, how awkward they felt facing the other one, with his aggressive tone. Or how appalling they found that other woman walking barefoot with her baby in her arms. Therefore, describing the civility rules that apply in public, such as "civil inattention" (Goffman 1963), is not enough to understand what is at play there.

Another example is that of gender relations in public. Women's experience of urban public life today involves equality between men and women in an interesting way (Gardner 1995; Gayet-Viaud 2010). Is the gender criterion always relevant? When does it become relevant? Sometimes it is seen as relevant for some, but not for others. Civility deals with the capacity to decide the criteria through which we should orientate our mutual conduct. When being talked to or offered unwanted help, how to answer correctly is not a matter of rules only. One has to be attentive to the issues at stake, that is, not to give false hope by receiving too well, or being too generous, not encouraging unwanted gestures or disapproving attitudes, but not presuming guilt and being unfair by presuming that the help offered is fake, a way of initiating seduction. 
Yet another example is age, which, for instance, has long been a source of authority and now it is less and less. Yet, a child is still considered very broadly as a kind of "public good" (Goffman 1971; Cahill 2010; Gayet-Viaud 2006), that is, someone for whom responsibility is partly shared by all the adults present. All situations in which people are not sure what to do involve difficulty combining what is commonly accepted and what is fair. Opposing appearance to reality or to forms or conventions is, therefore, misleading and misses what is really at stake in civil interactions. Civil interactions test the meaning of concepts and ideas about the larger society, about democracy as a way of living together. They test gender interactions, they test perception of poverty and boundaries of charity, compassion and solidarity, through active situations.

\section{Civility as an Experience} honour, a means of democratic socialization, civility is one of the most common and yet neglected public experiences. It has to do with meddling, intervening, talking, showing care and attention, sometimes fighting, trying to teach things to others. It belongs to the everyday tests and expressions of the common good:

Beneath the vocabulary and paradigm of 'action,' it points to an understanding of citizenship as an experience, that is, something that is more comprehensible in terms of attention and perception, attachment and care, ordinary expressions of what is valuable. (Diamond, 2001)

There is, of course, a whole range of possibilities from mechanical low-level civil activity to committed engagement in a public interaction or a public scene in order to do what one thinks is right. Not all interactions are plainly committed to and all of them do not presuppose a lot of reflexive critical work, of course. But many of them do. We therefore have to describe those variations in detail. As Pharo (1985) described, civility encompasses some forms of active gestures, directly interpretable in terms of public spirit. Pharo calls them "civil interventions," and defines them as standing between the explicitly "militant forms" of relating oneself to the Polis and some of the more implicit forms of common good encompassed in ordinary more routinized practices of civility. Civil interactions perform measured and limited forms of commitment and reflexivity about those forms, their right content, extent. To what extent is it necessary, possible, and desirable to intervene? How far should one go? The concrete and even material circumstances of the situations may be decisive, of course. Not doing something does not always mean not caring, it can also mean feeling helpless (Gayet-Viaud, 2010), not knowing what to do, how to do the right thing. It actually occurs in a great many situations.

These variations of civil exchange and degrees of commitment are ways of being concerned, of taking part in situations: in which we discover and defend what we owe one another. At the opposite of a presentist perspective of the interaction order, they point to a truly iterative process. The intervention takes place in a series of public situations that matter as such, add to one another, where people answer a series of past occurrences (Gayet-Viaud 2011b) as much as to the present situation, or even anticipate possible future ones. ${ }^{8}$

32 Categorization of course plays a big part in this process of accumulation between episodes. What people experience is not a generalized other but typified others. 
ity has often been understood as involving settings presenting all the characteristics of theatre, that is, unity of time, place, and action. The interaction order defines a set of rules and requirements that come into play as though they were happening for the first time. There is no real experience there to reflect upon because the requirements are preexisting and are not within reach of the participants/actors. People work hard to achieve and perform their part of the play, to become competent as performers, and they can become progressively socialized in this way. But from this perspective their civil interactions do not participate in an experience that goes beyond itself. The only horizon is being a good performer. What ethnographic observation and interviews show, on the contrary, is that people reflect upon how to be good in those situations too. They try and behave in different ways, for example vis-à-vis beggars, they give to everyone they meet, then they do not give any more, or maybe only to the one who is local to where they live. And they have a story about how they think about it. Sometimes, they are in a hurry and they do not think at all. Their practices can be routinized. They are not troubled all the time by all the issues that arise in civil interactions. But they feel troubled much more often than they will admit.

\section{Categorization, and Reflexivity Towards Categories: The Everyday Fabric of a Political and Moral Culture Through Civility}

In civil interactions, ordinary categorization (Jayyusi 2010) or typification (Schütz 1962; 1970) should not be considered merely as a resource but also as a theme of critique, and even quarrel, which contributes to forming the citizen's perception and opinion of the world they live in. Indeed, categories of mutual perception are not only instruments for perception and regulations of conducts, they also frequently become matters of selfreflection, discussion, anticipation, critique, and even conflict. Many examples can be given, some of the most salient politically involve definitions of: homelessness and begging, racial interactions (Anderson 2011), religious interactions (Tavory 2011), or gender interactions (Gardner 1995).

Following the attack on the 'Charlie Hebdo' offices in Paris in January 2015, people in the streets and the métro became aware of things they previously did not notice. Some aspects of situations became relevant that were not relevant a few days ago. Everybody mentioned the incident, it became a source of great interest. People who looked like Arabs (most Muslims in France come from North Africa) were looked at differently, became objects of suspicion: whilst everybody was expected to feel grief and 'national unity,' people speaking in Arabic were frowned upon or looked at suspiciously. In a train, on the day of the big march of solidarity for the victims on January 11, a woman with her companion started to comment harshly about two men a few feet from them who were talking in Arabic: "How dare they," she mumbled with anger. Other people immediately turned to see who had spoken in this way and stared with disapprobation. Her companion then murmured to her and she stopped talking.

For a few weeks, people began talking more easily than usual of their perceptions of others, and the possible implications of these perceptions for democracy. They were prompted to evoke them, think about them, condemn them. Suddenly, what people looked like mattered differently. One could hear people say in a crowded train: "Hey, be

European Journal of Pragmatism and American Philosophy, VII-1 | 2015 
patient OK. With what's been going on we don't need to... OK...." It was not necessary to spell things out. What was shared in common became public, both clearly and discursively. People articulated what they cared about in their civil interactions and in their public life, that is, the right not to be a suspect. the importance of trust between strangers.

The same day of the march in the crowded train returning from Place de la Nation (line 2) when the train stopped at Pigalle, we heard the usual public transportation announcement warning people of potential pick-pockets active in the station. Usually such announcements seem relevant and normal. But that day it sounded inappropriate and ridiculous. There was a huge spontaneous laugh in the carriage. It sounded like a 'citizens' laughter,' expressing a sense of what related the people in this carriage, what security was (really) about, suggesting what was the nature of the trust there and then, between people.

These two last examples are of course very unusual, related to exceptional events. Nevertheless, they show in a more visible way energies that are at work in more ordinary times and situations. Because ordinary contexts do also bear this stake of 'categorization vigilance':9 elderly people pay attention to what they are thought of as a category accordingly for "the young." Denouncing discrimination is a way of refusing the negative implications that can be brought about by some categories, or even refuse the very relevance of a given category in a given situation. Categories and the norms, values, and qualities attached to them are an issue, a matter of reflection and even dispute. Hence: "Be careful, or the lady is gonna think that young people are rude." "Who do you think you are?" 10 People argue about what they think they are and what they think it means to be older/a woman/a Muslim/a beggar, and so on. They argue about what it is to be older: does it accompany authority? They argue about what is means to be a woman: does it mean that men can talk to them and ask for their number randomly in the street? Does it mean one has to be gallant and helpful? They argue about what it means to wear such or such clothes, to speak a foreign language, or have an accent, or to speak loudly.

This ordinary work that people accomplish to orientate their conduct between strangers, relying upon mutual perception and categorization, is essential to democratic life. For categorization is work on norms. It is not only a resource for perceiving what the situation is: defining a problem is already halfway to answering it, it configures the questions which a course of action should answer. When we see a child, a Rom, a thief, we do not see the same thing. Our categories - young, elderly, men/women, homeless, Rom, Jewish, gay, bourgeois - are tested and fought for. Their relevance, and their normative implications.

\section{Is 'Urban Public Space' a Mere Metaphor? Trust Between Strangers or Democracy as a Form of Sociability in Everyday Life}

39 A pragmatist approach to civility reveals the flaws of the dominant, superficial and ritualistic definition of civility. Civility is not so much the virtue of (certain) people, not even, or not only, the quality of (certain) conducts, as an activity undertaken by everyone, taking place between people when they are among strangers to define what they owe one another..$^{11}$ Being strangers to one another is not an obstacle but the very condition of civility, in its relation to hospitality. It does not have to be overcome. It is as 
strangers that we grant each other respect and trust. Through this routine activity, people practically define, in everyday interactions, what it means to be a co-citizen: what strangers can expect from one another, can ask each other, how they can trust each other, how they can perceive each other, what help they can expect from one another, or what they should fear or suspect, and so on.

If democratic public spaces are often said to designate an abstract political space where ideas are discussed and opinions are forged, as the Enlightenment philosophers called for, or as Habermas defined it, urban public space could be seen as no more than a metaphorical use (and maybe an abusive re-reading) of the traditional concept (Joseph 2006; Genestier, Ouardi \& Rennes 2009; Terzi \& Tonnelat 2013). What makes public spaces public? Considering civility as being a part of this practical accomplishment of democracy, enables us to rethink the link between urban public space, everyday experience, and democracy.

Such a link appears in the contemporary ethnography of urban civil interactions, where the two dimensions of the public discussed above are intertwined and elaborated together through ordinary practices and conducts. But this link is also documented by historians who studied the French Revolution and the growth of democratic public spaces in 18th century France, showing that the diffusion of new ideas, of critique, spread through cafés and salons, through the beginnings of a free press, and also took the form of a new culture of sociability. Didn't the famous 'Sans Culottes' try to create entirely new forms of civility, imposing 'tutoiement,' demanding that everybody call each other 'Citizen'?

The most durable change took the form of an entirely new urban hospitality. People had, for the first time, equal rights not only to talk or express their opinions, but also to be there and to come and go, to take their place (Joseph 1998) without having to justify their identity, who they were, or where they came from (Cottereau 1992). For the first time, people were granted trust without having to prove that they could be trusted, by referring to someone being a warrant for them. Civility therefore played a great part in this revolutionary change for democracy. It was a matter of giving people credit. It still is: in case of uncertainty (which is very often the case between strangers), civility requires giving credit and, as much as possible, allowing the benefit of the doubt as to what the others' intentions might be. People are presumed trustworthy. That is why urban public spaces and political public space are related more than metaphorically, but through sociability.

Since the French Revolution, civility as an activity, has remained a way through which people work on this same challenge, passing conventions through the requirements of political principles such as equality, liberty, and fraternity. Forms of civility, therefore, evolve, as are transformed relations between women and men, between classes, between generations, between races, between religious beliefs or sexual orientations. Civility is an activity in which all these questions, and issues are dealt with they appear in practice, are expressed, and are sometimes fought for.

Civility embodies places and times, when people act towards one another as equal cocitizens. Mickael Sandel's What Money Can't Buy (Sandel 2013) insists, quite rightly, on the threat that the (re)importation of some private and merchant criteria into public places and public services represents. It is of core importance for a democracy that there are such times and places at which people are not seen and treated according to their 
conditions, or how much money they earn, but are treated as equals. The very sense of being members of a community (of belonging to it and being an active part of it) depends on this. What is relevant from a civil point of view are not the differences arising from a personal or professional perspective. But such differences can encompass physical personal aspects. Some fragilities or some needs, in given situations, may be perceived as justifying specific treatment. All this is tested in situations. Legitimacy is the last criterion, ever at work, for defining what civil relations are like, what they should accommodate, and what they should ignore. Rethinking civility as this everyday activity makes it part of democracy as a way of life, and part of citizenship as an on-going experience.

\section{Conclusion}

Civility, when studied as an activity, proves to be one of the ways in which citizenship is experienced. It allows one to test what goes with this kind of link. It has no background to rely upon, except for the mere fact of being co-members in a political/moral community. It displays the tensions between a given state of social expectations and habits, and a vision of what those habits or facts should be. It represents a way of actually dealing with these two dimensions in real life. Civility means a way of trying to define, from within situations, what should be done, what can be done, at the very moment of doing. It performs and exhibits a state of the art of democracy as a political and moral culture, and at the same time shows how this process is always defining itself, always asking whether the rules that are applied are legitimate, and trying to improve upon them. Not only do sociologists or philosophers watch people acting and ask themselves what their conduct and its evolutions mean. People themselves practice a 'folk sociology' all the time (Schütz 1962; Schütz 1970; Anderson 2011) the implications of which are crucial to democratic life. Civility is one of the spaces in which such silent, under-observed, and, ordinary politically-oriented work takes place.

\section{BIBLIOGRAPHY}

ANDERSON E., (2011), The Cosmopolitan Canopy. Race and Civility in Everyday Life, New York/London, Norton Books.

ARENDT H., (1958), The Human Condition, Chicago, University of Chicago Press.

BIDET A., QUÉRÉ L. \& G. TRUC, (2011), “Ce à quoi nous tenons. Dewey et la formation des valeurs," introduction to Dewey J., La formation des valeurs, Paris, La Découverte ("Les empêcheurs de penser en rond"), 2011, 5-64.

Bidet A., boutet M., Chave F. Gayet-Viaud C. \& E. le mener, (2015), "Publicité, sollicitation, intervention. Pistes pour une étude pragmatiste de l'expérience citoyenne," SociologieS ("Pragmatismes"), premier semestre [sociologies.revues.org/4941]. 
BOLTANSKI L. \& A. ESQUERRÉ, (2014), Vers l'extrême. Extension du domaine de la droite, Paris, Éditions du Dehors.

CEFAÏ D. \& I. JOSEPH (eds.), (2002), L'héritage du pragmatisme. Conflits d'urbanité et épreuves de civisme, La Tour d'Aigues, Éditions de l'Aube.

COTTEREAU A., (1992), “"Esprit public et capacité de juger : la stabilisation d'un espace public en France aux lendemains de la Révolution," in A. Cottereau, P. Ladrière (eds.), Pouvoir et légitimité. Figures de l'espace public, Paris, Éditions de l'EHESS (“Raisons pratiques," 3), 239-72.

DEWEY J., (1938a), Experience and Education, London \& New York, Macmillan.

DEWEY J., (1938b), Logic: The Theory of Inquiry, New York, Holt (London, Allen \& Unwin, 1939).

DEWEY J., (2011), La formation des valeurs, Paris, La Découverte, ("Les empêcheurs de penser en rond"), French translation of Dewey J., (1939), Theory of Valuation, volume 2, no. 4 of International Encyclopedia of Unified Science, edited by Otto Neurath, Rudolf Carnap, Charles W. Morris, Chicago, University of Chicago Press.

DiAMOND C., (2001), "Le cas du soldat nu," Cités, 2001/1, 5, Paris, PUF, 113-25 (First published in French, translated from a Conference in West Point).

DURKHEIM É., (2003), Les formes élémentaires de la vie religieuse, Paris, PUF (“Quadrige”) [1960].

GARDNER C., (1995), Passing By. Gender and Public Harassment, Berkeley, University of California.

GARFINKEL H., (1967), Studies in Ethnomethodology, Englewood Cliffs, Prentice-Hall.

GAYET-VIAUD C., (2009), "La femme autonome et l'homme galant. Intransigeances du respect et acrobaties de l'égard dans la civilité urbaine," in M. Jouan \& S. Laugier (eds.), Comment penser l'autonomie, Paris, PUF (“Éthique et philosophie morale”), 2009, 389-406.

GAYET-VIAUD C., (2010), "Du passant ordinaire au samu social : la (bonne) mesure du don dans la rencontre avec les sans-abris," Revue du MAUSS 35, 435-53.

GAYET-VIAUD C., (2011b), "La moindre des choses. Enquête sur la civilité urbaine et ses péripéties," in M. Berger, D. Cefaï \& C. Gayet-Viaud (eds.), Du civil au politique. Ethnographies du vivre-ensemble, Bruxelles, PIE Peter Lang, 2011, 27-54.

GAYET-VIAUD C., (forthcoming), La civilité urbaine. Enquête sur les formes élémentaires de la coexistence démocratique, Paris, Economica ("Études sociologiques").

GAYET-VIAUD C. \& M. BERGER, (2011a), "Du politique comme chose au politique comme activité. Enquêter sur le devenir politique de l'expérience ordinaire," introduction to M. Berger, D. Cefaï \& C. Gayet-Viaud (eds.), Du civil au politique. Ethnographies du vivre-ensemble, Bruxelles, PIE Peter Lang, 2011, 9-24.

GoffmAn E., (1963), Behavior in Public Places. Notes on the Social Organization of Gatherings, New York, Free Press of Glencoe.

Goffman E., (1971), Relations in Public. Microstudies of the Public Order, New York, Basic Books.

GRANOVETTER M. S., (1973), “The strength of weak ties”, American Journal of Sociology, 78, 6, 1360-1380.

HABIB C. \& Ph .RAYNAUD (eds.) (2012), Malaise dans la civilité ?, Paris, Éditions Perrin.

JAYYUSI L., (1984), Categorization and the Moral Order, Routledge and Kegan Paul.

JOSEPH I., (1998), La ville sans qualité, La Tour d'Aigues, Éditions de l'Aube. 
LEFORT C., (1986), Essais sur le politique. XIX ${ }^{e}-\mathrm{XX}$ siècles, Paris, Seuil.

LOFLAND L. H., (1998), The Public Realm: Exploring The City's Quintessential Social Territory, Hawthorne, NY, Aldine de Gruyter.

OGIEN R, (1990), "Les sanctions diffuses, rire, sarcasmes et mépris," Revue française de sociologie,

XXXI, 4.

PHARO P., (1985), Le civisme ordinaire, Paris, Méridiens-Klincksieck.

PUTNAm H., (2002), The Collapse of the Fact/Value Dichotomy, Cambridge, Mass., Harvard University Press.

SACKS H., (1985), “On Doing ‘Being Ordinary'," Lectures on Conversation, Vol. II, edited by Gail Jefferson, Blackwell Publishers, Oxford, 1985, 215-21.

SANDEL M., (2012), What Money Can't Buy. The Moral Limits Of Markets, New York, MacMillan USA.

scHÜTZ A., (1962), Collected Papers, 2, Studies In Social Theory, La Haye, Martinus Nijhoff.

schÜTZ A., (1970), Reflexions On The Problem of Relevance, New Haven, London, Yale University

Press.

SENNETT R., (1977), The Fall of Public Man, New York, Knopf.

SIMmel G., (1950/1903), “The Metropolis and Mental Life," in The Sociology of Georg Simmel, New York, Free Press.

TASSIN E., (1992), "Espace commun ou espace public ? L'antagonisme de la communauté et de la publicité," Hermès, CNRS Éditions, 1, 10, 23-37.

TAVORY I., (2011), “À la vue d'une kippa,” in M. Berger, D. Cefaï \& C. Gayet-Viaud (eds.), Du civil au politique. Ethnographies du vivre-ensemble, Bruxelles, PIE Peter Lang, 2011, 55-75.

TERZI C. \& S. TONNELAT, (2013), "Espace public. Une définition," Dictionnaire critique et interdisciplinaire de la participation, mis en ligne le 28 juin 2013, [participation-et-democratie.fr].

ZIMMERMAN D. H. \& M. POLLNER, (1996/1970), “Le monde quotidien comme phénomène," Cahiers de recherche ethnométhodologique 2, 7-37, translated from "The Everyday World World as a Phenomenon" in J. D. Douglas ed., Understanding Everyday Life, Chicago, Aldine, 1970, 80-103.

\section{NOTES}

1. Goffman's dichotomy of appearances and authenticity has produced an ambiguous legacy. His works have accomplished a great deal in establishing the importance of interactions, and draw our attention to what people do in situations (their activity as performers). But he also constantly refuses to acknowledge the complex relation between the interaction order, appearances, and expressivity. Goffman repeatedly refuses to consider appearances as being real and neglects the possible importance for people of making the impressions they foster coincide with their actual feelings and thoughts. For example, in The Presentation of Self in Everyday Life: "In their capacity as performers, individuals will be concerned with maintaining the impression that they are living up to the many standards by which they and their products are judged. Because these standards are so numerous and so pervasive, the individuals who are performers dwell more than we might think in a moral world. But, qua performers, individuals are concerned not with the moral issue of realizing these standards, but with the amoral issue of engineering a convincing impression that these standards are being realized. Our activity, then, is largely 
concerned with moral matters, but as performers we do not have a moral concern with them" (Goffman 1959: 251).

2. This opposition also often takes the form of the classical opposition between the common and the public (for example, Tassin 1990); or (as in Tassin \& Murard 2006), an opposition between what it means to be a member of a community (belonging) and what it means to act as a citizen in this community. On the contrary, I try to describe and understand how those two "sides" of the social lives of citizens are intertwined. Studying democracy as a way of life means considering citizenship as an on-going experience (Bidet, Boutet, Chave, Le Mener \& Gayet-Viaud 2015).

3. Of course, Goffman and Sacks do not share the same position regarding the status of appearances (there is, for one thing, nothing such as a strategic actor in Sacks' perspective). But what is of interest for the present discussion is that both tend to underestimate how people evaluate (and not only perform) the norms, how they judge the routines of everyday life in which they have to fit, and how they criticize them or even try to transform them (through a criticism on categories and their taken-for-granted attributes, for instance).

4. The empirical data here referred to was gathered in an ethnographic research study conducted for my PhD in sociology at EHESS (Gayet-Viaud 2008). It took place in France, mainly in and around Paris, then in Le Havre, between 2000 and 2006 (Gayet-Viaud 2008; 2011; forthcoming).

5. As I argue elswhere (Gayet-Viaud 2011b), one of the problems raised in urban encounters is to know when to understand the other's conduct as a sign that they are not well-meaning or welleducated, given the fact that between strangers, pessimistic interpretations can arise rapidly (since people do not share common backgrounds with which to solidify their trust, but share an experience of categories only) and when to maintain a credit of trust about them. This means, more concretely, that when someone seems not to do what one would expect them to do (give up their seat or respect the queue, for examples), how do we understand their behaviour, how do we conduct the inquiry into their intentions without presuming them guilty? Observations of many conflicts between strangers show that civil requirements cannot be treated as "rights" that can just be claimed without causing trouble. When you claim civility as a right, you offend the one to whom you address your claim, affirming their incompetence, their failure. This proves that part of what is accomplished within civil interactions relies upon the fact that conduct displays and exhibits a genuine attention to others, and a mutual trust, that goes with granting others the initiative of giving you what you expect from them, that is, the "giver" to the "receiver."

6. Quotations here are all excerpts from my fieldwork observations and interviews.

7. That means not to ask people about civility in general, which easily gives way to media readymade opinions about its supposed decline: the more concrete the conversation is, the more stories people have to tell, that show how much these experiences matter to them.

8. Experience is, as Dewey defined it (1968), this very process: when people acknowledge what happens as a consequence of what they do or have done, when they learn from them or adapt to them. Experience is about how one's actions transform both their sensibility and their understanding of the world around them, or rather, their knowledge that also and sometimes firstly comes through sensibility.

9. 'Categorization vigilance' is the special attention people pay to the implications of the categories through which they are perceived by the others.

10. Excerpts from field note journal.

11. 'Stranger' here in the sense of Simmel 1908 and Lofland 1973, meaning people who are unacquainted. 


\section{ABSTRACTS}

By taking seriously the idea that democracy is a way of life, a pragmatist approach to democracy invites us to reconsider how manners and the political realm of free thought may be related. The present contribution argues that civil interactions are part of the experience of citizenship and represent one of the ways through which political principles can come to life. Civility is therefore described as an activity rather than a set of rules, the role of which in democratic life has been often underestimated. In civil interactions, people struggle and hesitate, and even fight to establish conditions of respect, trust, solidarity, or authority. They practically define the bond between people who have nothing more in common than living in the same society. Far from being a mere mechanical or conservative repetition of inherited habits, civil interactions, when studied closely, exhibit the constant effort people make to promote what they care about. Civility should therefore be considered as an activity the difficulties associated with which aim at embodying through sociability, the political link between citizens. Hospitality to difference, helpfulness, attention to others, even quarrels over what is fair, discussions and reflections about the relevance of the categories through which people perceive one another, have to be analysed in this perspective, as effective parts of the activity of caring for the common world.

\section{AUTHOR}

\section{CAROLE GAYET-VIAUD}

CESDIP-CNRS

carole.gayetviaud[at]cesdip.fr 